\title{
INOVASI ALAT PERAGA EDUKATIF BERMAIN CERDAS (BCD's) UNTUK MEDIA PEMBELAJARAN BAGI ANAK PAUD
}

\author{
Sodik $^{1 *}$, Muhammad IIman Nur Sasongko ${ }^{2}$ \\ ${ }^{1}$ Program Studi Akuntansi, Fakultas Ekonomi dan Bisnis, Universitas Widyagama Malang \\ ${ }^{2}$ Program Studi Teknik Mesin, Fakultas Teknik, Universitas Widyagama Malang \\ *Email Korespondensi: hmsodik4@gmail.com
}

Submitted : 2 September 2021; Revision : 9 September 2021; Accepted : 2 Oktober 2021

\begin{abstract}
ABSTRAK
Pendidikan Anak Usia Dini (PAUD) sangat memerlukan perkembangan motoric halus sebagai sarana bagi anak usia dini dalam menimba ilmu. Media pembelajaran sebagai sarana untuk mengenalkan berbagai ilmu pengetahuan bagi anak usia dini dan melatih motoric halus. Media pembelajaran yang baik menjadi ketertarikan anak usia dini dalam belajar. Keterbatasan media belajar menjadi masalah bagi PAUD. Pengabdian dengan membuatkan media belajar yang mampu menarik sangat dibutuhkan. Metode pelaksanaan dengan membuat disain alat peraga edukatif bermain cerdas (BCD's) dan buku sebagai sarana pembelajaran. Hasil pemanfaatan alat peraga edukatif BCD's sangat efektif bagi anak usia dini dengan hasil 4,6 menit untuk mengenal garis, 5 menit untuk mengenal bentuk geometri, 5,8 menit untuk mengenal angka, 11,4 menit untuk mengenal tanaman, 13,6 menit untuk penjumlahan, 14,9 menit untuk pengurangan dan 15 menit untuk menyambung huruf menjadi sebuah kata.
\end{abstract}

Kata kunci : PAUD, Alat Peraga Edukatif, Bermain Cerdas, Motorik Halus

\section{ABSTRACT}

Early Childhood Education (PAUD) really needs fine motor development as a means for early childhood to gain knowledge. Learning media as a means to introduce various sciences for early childhood and train fine motor skills. Good learning media becomes the interest of early childhood in learning. The limitations of learning media are a problem for PAUD. Devotion by developing interesting learning media is very much needed. The implementation method is by designing smart play educational teaching aids (BCD's) and books as learning tools. The results of the use of BCD's educational teaching aids are very effective for early childhood with the results of 4.6 minutes to recognize lines, 5 minutes to recognize geometric shapes, 5.8 minutes to recognize numbers, 11.4 minutes to recognize plants, 13.6 minutes to addition, 14.9 minutes for subtraction and 15 minutes for connecting letters into a word.

Keywords : Early Childhood Education, Smart Playing, Educational Teaching Aids, Fine Motoric

\section{PENDAHULUAN}

Di Indonesia pendidikan anak usia dini (PAUD) telah berkembang dengan baik dan dipersiapkan untuk menuju tumbuh kembang anak agar menjadi pribadi yang lebih baik, (Noveradila \& Larasati, 2015). Pendidikan anak usia dini (PAUD) merupakan klasterisasi dalam pendidikan dengan rentang usia anak antara 0 sampai dengan 6 tahun. Pendidikan bagi anak usia dini atau PAUD diatur dalam Undang-Undang Sisdiknas Nomor 20 Tahun 2003, hal ini diharapkan bahwa pembinaan anak masuk dalam PAUD mulai dirangsang untuk mendapatkan pendidikan guna membantu anak usia dini dapat memperlihatkan perkembangan fisik, motorik halus dan kasar, kognitif, bahasa, serta rohaninya untuk kesiapan masuk pendidikan selanjutnya, (Sulaiman et al., 2019). Motorik halus akan berpengaruh pada anak dilihat dari moral agama, sosial emosional dan seni sehingga mampu berkembang dengan pesat (Evivani \& Oktaria, 2020). 
Anak usia dini harus diperhatikan pada masa perkembangan motoriknya karena akan berpengaruh terhadap kehidupannya di masa yang akan datang. Masa golden age yaitu masa pendidikan untuk perkembangan IQ anak sehingga menjadi penting untuk diperhatikan karena akan membekas di benak anak dan akan dibawa sampai tua. Daya tangkap otak anak di masa golden age akan mampu menyerap semua informasi yang pesat dan menjadi pusat kecerdasan, disamping itu menjadi tahapan pertumbuhan fisik dan mental anak. Oleh karena itu, untuk mempersiapkan di masa anak usia dini perlu sentuhan alat edukatif dalam membantu perkembangan otak dan ketrampilan anak untuk memahami kasus sederhana dengan memanfaatkan jari dan tangan (Yulianto \& Awalia, 2017). Menurut Ilato, (2020), kemampuan usia 3-4 tahun dalam mengasah motorik halus dapat dilakukan dengan cara bermain dalam bentuk puzzle untuk mengasah ketrampilan otak, jari dan tangan hal ini sependapat dengan pendapat Yulianto \& Awalia, (2017).

Alat yang dapat dipakai untuk merangsang motorik halus yaitu seperti gunting, bentuk permainan puzzle dapat diberikan kepada anak sesuai umurnya untuk pembelajaran ketrampilannya (Asriah et al., 2021). Bentuk permainan edukatif sangat menarik untuk diberikan kepada anak usia 3-6 tahun dalam belajar mengenal matematika, karena dapat menstimulasi dari kecerdasan anak, (Noveradila \& Larasati, 2015). Dasar pemikiran alat edukatif dengan bentuk permainan berfungsi bisa mengerakan bagian dari anggota tubuh anak secara bebas sehingga mampu menggerakkan cara kerja otak menjadi tetap terjaga. Oleh karena itu menjadi penting dalam memilih bentuk permainan untuk dapat merangsang motorik halus anak usia dini yang akan di pakai dalam bentuk media pembelajaran agar proses belajarnya dapat optimal (Utami, 2016). Disamping itu diperlukan pula pemilihan material pembelajaran yaitu dipilih yang foodgrade, hal ini dikarenakan anak usia dini masih cenderung memasukkan benda ke mulut.

Pengabdian kepada masyarakat dilakukan di PAUD desa Pandansari Kabupaten Malang. Fasilitas yang dimiliki PAUD sangat sederhana baik dari media pengenalan huruf, angka, bidang geometri sehingga menjadi program untuk pengabdian. PAUD di desa Pandansari sangat terbatas jumlahnya, anak usia dini kesekolah ada yang jaraknya dari rumah sekitar $5 \mathrm{~km}$ dan tidak ada alat transportasi. Masyarakat di desa Pandansari sangat antusias untuk menyekolahkan anak-anaknya untuk dapat menyiapkan ke jenjang pendidikan yang lebih tinggi dengan mudah.

Persoalan yang dapat diambil dari kondisi eksisting tersebut terletak pada media pembelajaran yang masih sangat sederhana dan jumlahnya hanya satu dan ditempel di dinding tembok dan situsi pembelajaran yang tidak berjarak (dilihat pada Gambar 1). Melihat media yang dipakai dalam pembelajaran anak PAUD sangat memprihatinkan, maka solusi yang dapat diambil yaitu dengan membuatkan media pembelajaran yang lebih mudah, anak tidak jenuh, penuh tantangan untuk belajar, dan bisa dipakai untuk bermain. Inovasi yang dapat dikembangkan akan diterapkan di PAUD desa Pandansari, Kabupaten Malang adalah dengan membuatkan alat edukasi dalam bentuk permainan yang foodgrade.

\section{METODE}

Alat peraga edukatif sebagai sarana untuk belajar dengan cara bermain dibuat untuk memudahkan anak usia dini bisa belajar dengan baik dan nyaman. Alat peraga edukatif yang dibuat diberi nama Bermain Cerdas atau disingkat dengan BCD's. Tahapan yang dapat dilakukan untuk membuat alat edukatif bermain cerdas (BCD's) adalah sebagai berikut:

1. Memilih mitra untuk diajak kerjasama dan memecahkan persoalan yang terjadi pada media pembelajaran edukatif yang ramah lingkungan.

2. Memilih dan menyetujui untuk membuat alat peraga edukatif mulai dari mengenalkan garis dengan beberapa bentuk antara lain: garis lengkung, garis putus-putus, angka, alphabed atau huruf, operasi penjumlahan, operasi pengurangan, baik penjumlahan dan pengurangan langsung dari angka-angka atau dalam bentuk gambar, penyambungan 
huruf sehingga membentuk kata. Alat peraga edukatif ini dibuat dengan model permainan yang inovatif dan mudah dikerjakan oleh anak usia dini.

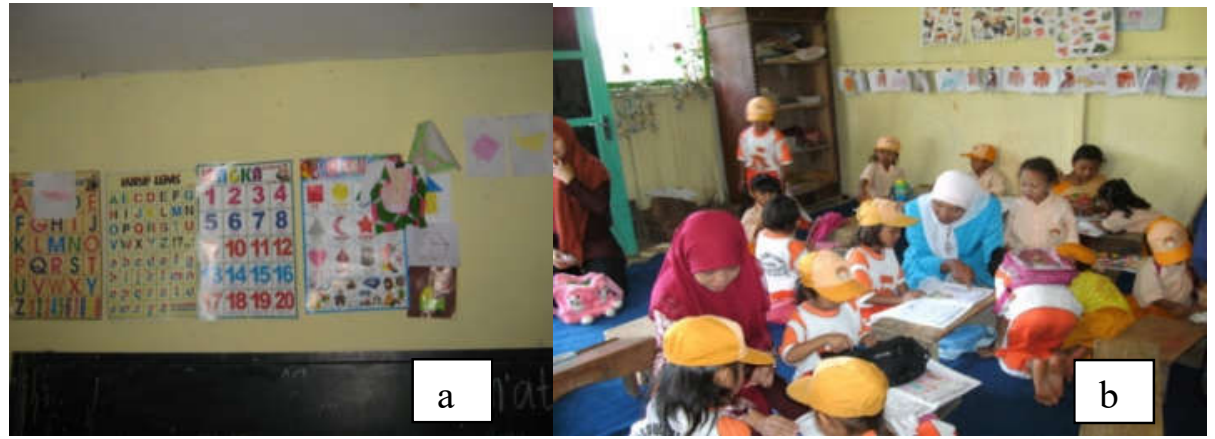

Gambar 1. a) Peraga Alphabet, Angka, Geometri Motorik Halus, b) Suasana Pembelajaran PAUD di Desa Pandansari Kabupaten Malang

3. Membuat desain alat peraga dalam bentuk rangka dari kayu

4. Memberikan bentuk desain ke tukang mebel untuk dikerjakan sesuai dengan ukuran yang telah disepakati.

5. Alat peraga edukatif ini dilengkapi dengan buku bermain cerdas (BCD's). Pembuatan buku sebagai kelengkapan dari alat peraga edukatif bermain cerdas (BCD's) dengan konten berupa pengenalan garis: garis lurus, lengkung, siksak, garis putus-putus; pengenalan angka 1-20; pengenalan huruf: ada 26 huruf; pengenalan bidang geometri: lingkaran, tabung, segitiga, persegi panjang, segi empat; membuat rangkaian huruf menjadi kata; pengenalan tanaman bunga; penjumlahan; pengurangan. Membuat kunci jawaban dari setiap topik pembicaraan dari setiap konten atau isi buku BCD's.

6. Melakukan uji coba ke pada anak usia dini (PAUD)

7. Perlakuan selanjutnya adalah dengan melakukan evaluasi dari penggunaan alat peraga edukatif bermain cerdas (BCD's) yang diterapkan pada anak-anak PAUD.

Adapun tahapan dalam pembuatan alar peraga edukatif Bermain Cerdas atau BCD's ini dapat dilihat pada Gambar 2. Alat peraga edukatif bermain cerdas (BCD's) sebagai salah satu model pembelajaran motorik halus yang dirancang untuk pembelajaran dengan konsep bermain yang dapat diterapkan pada anak usia dini (PAUD) dengan memakai logika. Oleh karena itu, rancangan alat peraga edukatif bermain cerdas (BCD's) dibuat sesederhana mungkin dan tidak berbahaya bagi anak usia dini (PAUD). Disain alat peraga edukatif bermain cerdas (BCD's) berupa rangka kayu dengan bentuk persegi empat memakai ukuran yang tidak terlalu besar yaitu panjang $24,5 \mathrm{~cm}^{2}$ dan lebar $24,5 \mathrm{~cm}^{2}$ dan dibuat sebanyak 2 lembar dan tengahnya ada engsel untuk bisa dibuka dan ditutup. Alat peraga ini kemudian dibagi menjadi 32 lubang persegi empat kecil dengan ukuran panjang $5 \mathrm{~cm}^{2}$ dan lebar $5 \mathrm{~cm}^{2}$. Lubang persegi empat kecil akan diisi dengan balok kecil dengan ukuran panjang $4,5 \mathrm{~cm}^{2}$ dan lebar $4,5 \mathrm{~cm}^{2}$ sedangkan jumlahnya sebanyak 16 biji, balok ini selanjutnya di beri nama pion. Pion yang terbentuk kemudian di beri angka 1 sampai dengan 16 dan dibalik pion dicat dengan warna: merah, hijau, kuning dan biru. Peraga BCD's ini dilengkapi dengan buku bantu dan kunci berupa kotak warna-warni ditempatkan pada sisi kanan atas.

\section{Pembuatan Jadwal}

Pembuatan alat peraga edukatif bermain cerdas (BCD's) membutuhkan waktu yang lumayan panjang yaitu sekitar 6 bulan. Proses yang lama adalah saat pembuatan kunci dari alat BCD's ini. Buku peraga mempunyai dampak terhadap setiap pokok bahasan dan harus dibuatkan kunci jawaban dengan memadukan pada alat peraga berupa angka dan warna balok yang tersusun. Berikut jadwal kegiatan yang dapat dilihat pada Gambar 3. 


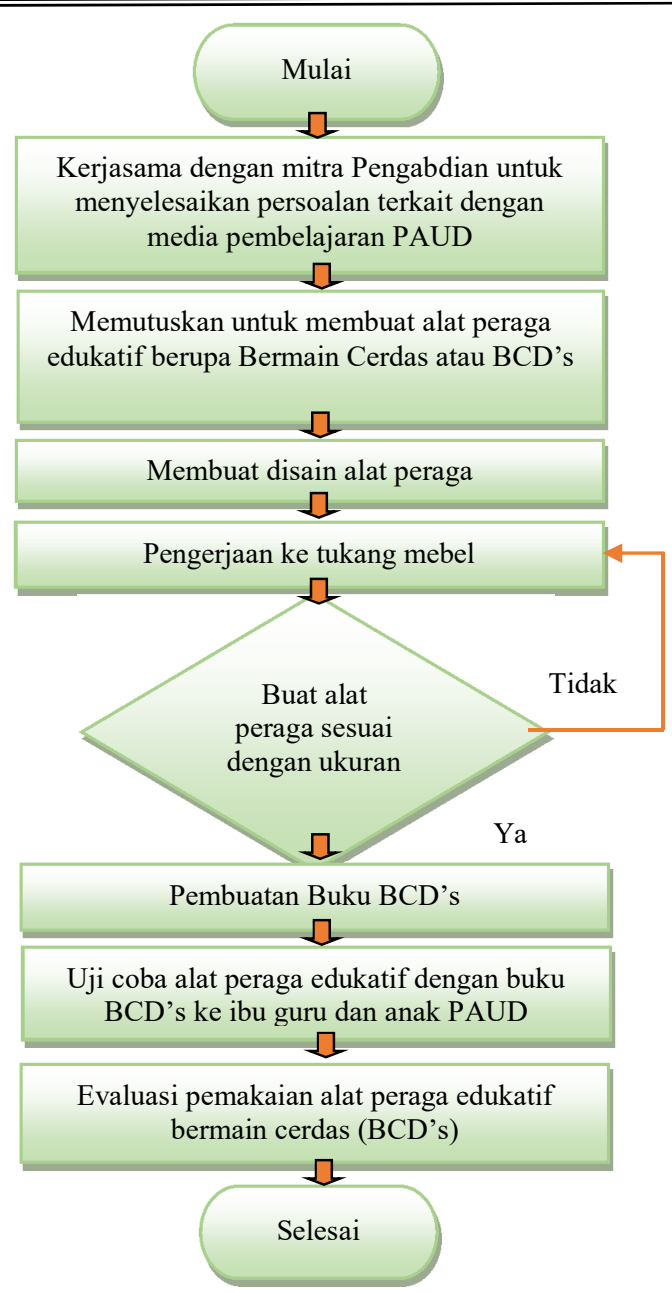

Gambar 2. Tahapan Metode Pelaksanaan Pembuatan Alat Peraga Edukatif BCD's

JADWAL PEMBUATAN ALAT PERAGA EDUKATIF BERMAIN CERDAS (BCD's)

KETERANGAN

Disain Alat Peraga Edukatif BCD's

Pembuatan Buku Konten Garis

Pembuatan Buku Konten Angka 1-20

Pembuatan Buku Konten Huruf 26 Abjad

Pembuatan Buku Konten Geometri

Pembuatan Buku Konten Jenis Tanaman Bunga

Pembuatan Buku Konten Penjumlahan

Pembuatan Buku Konten Pengurangan

Pembuatan Buku Konten mengandeng huruf jadi kata

Membuat Kunci Jawaban Pada Buku BCD's

Uji Coba Ke Anak Usia Dini dan lbu Guru

Evaluasi dan Efisiensi Penggunaan Alat Edukatif Bermain Cerdas (BCD's)

Gambar 3. Jadwal Pembuatan Alat Peraga Edukatif Bermin Cerdas (BCD's)

\section{Bulan ke 1 Bulan ke 2 Bulan ke 3 Bulan ke 4 Bulan ke 5 Bulan ke 6}

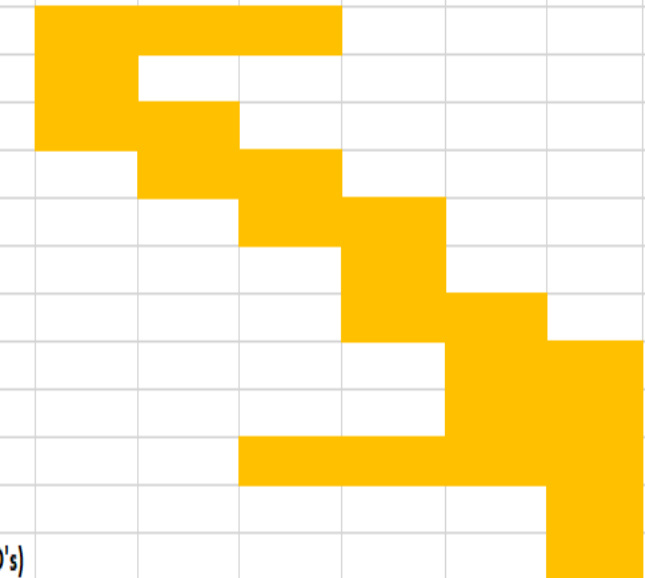




\section{Pembuatan desain dan penentuan material}

Desain alat peraga edukatif bermain cerdas (BCD's) bagi anak usia dini (PAUD) dibuat untuk memudahkan anak dalam memahami tentang pokok bahasan satu persatu dengan teknik bermain dengan menggunakan logika berpikir, jari dan tangan bekerjasama dengan baik. Oleh karena itu perlu dilakukan pembuatan desain alat yang dapat dilihat pada Gambar 4.

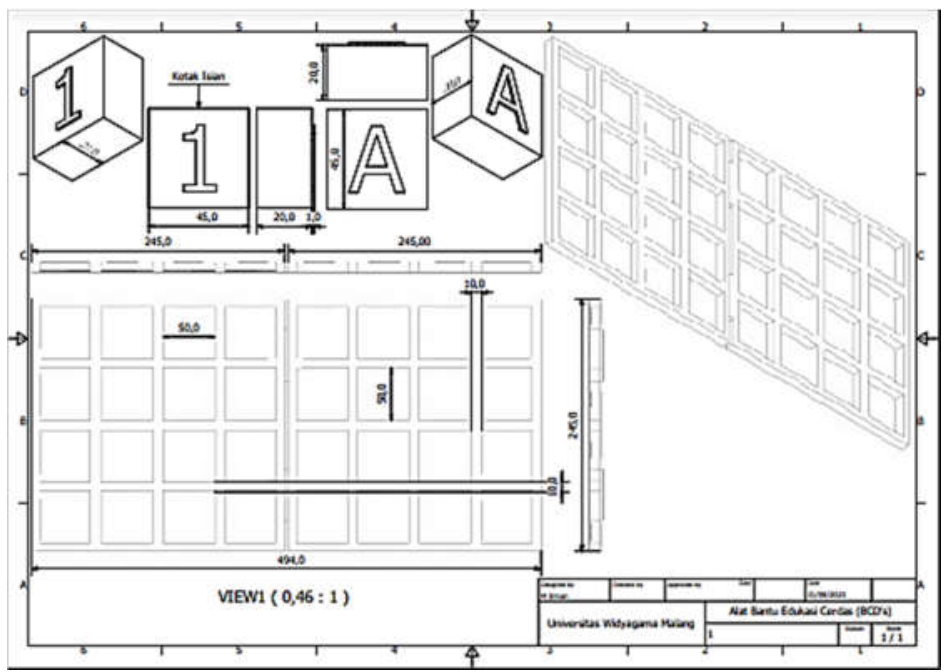

Gambar 4. Disain Kerangka Alat Peraga Edukatif Bermain Cerdas (BCD’s)

Langkah pengerjaan alat edukatif dibagi menjadi dua bagian yaitu:

1. Proses pembuatan frame atau kerangka alat peraga edukatif dalam bentuk kayu

2. Mengerjakan frame atau kerangka alat peraga edukatif bermain cerdas (BCD's) dengan cara memotong kayu, membentuk menjadi persegi empat dan dibuat 2 lembar kemudian di gabung dengan memakai engsel agar bisa dibuka dan ditutup, setiap lembar dibagi-bagi lagi menjadi 16 kotak: membuat pion untuk melengkapi alat peraga edukatif ini, selanjutnya bisa dilihat pada Gambar 5.



Gambar 5. a) Kerangka BCD's yang Dibuka Menjadi Dua Sisi Setiap Sisi 16 Kotak Persegi Empat, b) Bentuk Pion Berupa Balok, c) Kerangka BCD’s Kondisi Ditutup dan Dipasang Pion

3. Bentuk alat peraga edukatif bermain cerdas (BCD's)

Bentuk alat peraga edukatif bermain cerdas (BCD's) yang sudah jadi dan frame atau rangka alat peraga edukatif (BCD's) di cat dengan warna coklat dan pink dengan cat yang foodgrade artinya aman bagi anak usia dini dan setiap pion di tulis dengan angka dari 1 sampai 16 dan bagian bawah pion di beri warna merah berjumlah 4 pion, hijau berjumlah 4 pion, biru dan kuning juga berjumlah masing-masing 4 pion. Pemberian warna dimaksudkan untuk memudahkan dalam pembuatan kunci yang di nantinya akan disinergikan dengan buku bermain cerdas (BCD’s) bisa dilihat pada Gambar 6. 


\section{\begin{tabular}{|l|l|l|l|}
\hline 1 & 2 & 3 & 4 \\
\hline 5 & 6 & 7 & 8 \\
\hline$\overline{9}$ & 10 & 11 & 12 \\
\hline 13 & 14 & 15 & 16 \\
\hline
\end{tabular}}



Gambar 6. Bentuk Lengkap Alat Edukatif Bermain Cerdas (BCD's) Baik Dari Sisi

Angka dan Warna Pion Merah, Hijau, Biru dan Kuning.

4. Pembuatan Konten Buku Bermain Cerdas (BCD's)

Buku edukatif bermain cerdas (BCD's) dibuat sebagai pelengkap alat peraga edukatif bermain cerdas (BCD's) yang terbuat dari bingkai atau frame kayu. Fungsi buku memberikan pembelajaran yang tersusun sesuai dengan konten dari materi yang terdapat dalam pembelajaran motorik halus yang terdiri dari: pengenalan berbagai bentuk garis, bentuk geometri berupa: persegi empat, persegi panjang, lingkaran, segi tiga; tanaman berbagai jenis bunga; angka sebagai pengenalan kepada anak usia dini dari angka 1 sampai dengan angka 20, alphabet atau huruf sebanyak 26, pengenalan tanaman berbentuk bunga, penjumlahan, pengurangan, membuat kata dari beberapa huruf. Berikut Gambar 7 menjelaskan sebagian konten dari buku BCD's



Gambar 7. Sebagian Konten dari Buku BCD's 


\section{Pembuatan Kunci Jawaban setiap lembar kerja dari buku BCD's}

Pembuatan kunci jawaban buku BCD's menjadi penting untuk melihat hasil pekerjaan yang dilakukan oleh anak usia dini dalam bermain dengan menggunakan buku BCD's dan memudahkan bagi guru untuk cepat menilai hasil pengerjaan dari anak untuk belajar dari berbagai konten. Berikut Gambar 8 sebagai bentuk kunci jawaban.
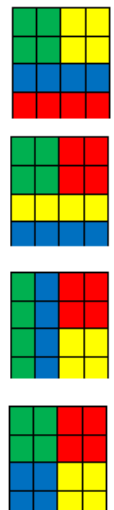
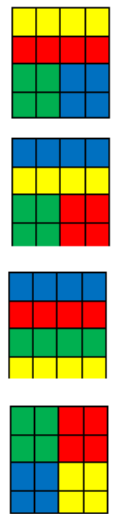
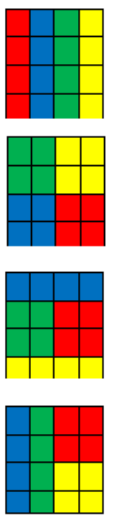
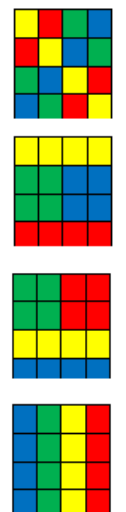


Gambar 8. Pembuatan Kunci Jawaban Dari Buku BCD’s

\section{HASIL DAN PEMBAHASAN}

Inovasi alat peraga edukatif bermain cerdas (BCD's) sebagai salah satu bentuk media pembelajaran motorik halus dalam bentuk permainan dengan mensinergikan penggunaan logika berpikir bagi anak usia dini dengan pemanfaatkan alat berupa bingkai atau frame terbuat dari kayu dan dilengkapi dengan buku (BCD's) dengan konten tentang pengenalan berbagai bentuk garis, bidang geometri, angka, alphabet, tanaman bunga, penjumlahan, pengurangan, penyambungan huruf menjadi sebuah kata, dengan melihat kata kunci dan jawaban yang ditunjukkan dengan hasil warna yang terbentuk. Alat peraga edukatif ini mampu memberika kenyamanan pada anak usia dini sehingga bisa belajar dari rumah dengan pantauan orang tua atau bisa juga belajar disekolah. Alat ini sangat efektif untuk belajar dalam pengenalan berbagai garis, bentuk geometri, angka, huruf, pengenalan tanaman dari beberapa bunga, penjumlahan sederhana sampai dengan angka 20, pengurangan sederhana sampai angka 20, belajar membaca dengan memadukan antara huruf dengan huruf lain sehingga menjadi kata. Peraga edukatif ini membuat anak mudah belajar, berpikir dengan logika, kecermatan, ketepatan, dan menarik untuk dimainkan. Alat peraga edukatif bermain cerdas bisa melatih daya tangkap bagi anak usia dini menjadi cepat.

Alat peraga edukatif bermain cerdas (BCD's) ini dapat dipergunakan untuk menyederhanakan dalam proses belajar mengajar secara nyata karena langsung dalam bentuk praktek. Anak-anak lebih senang menerima penjelasan dari guru atau orang tua secara langsung dengan melihat bentuk dan gambar dalam bentuk nyata. Hasil yang dapat diperoleh adalah anak lebih senang, nyaman, mau mencoba, dan bermain dengan logika. Berikut adalah cara penggunaan alat peraga edukatif bermain cerdas (BCD's) sebagai berikut:

1. Orang tua atau guru menjelaskan topik yang akan dikerjakan ke anak usia dini.

2. Setiap halaman buku BCD's ada pertanyaan yang harus dikerjakan sesuai perintah dari buku tersebut yang bisa disampaikan oleh ibu guru atau orangtua kepada anak usia dini.

3. Lihat kunci jawaban ada diatas buku BCD's.

4. Buku BCD's dibuka sesuai topik bahasan kemudian bingkai atau frame alat peraga edukatif diletakkan diatas buku BCD's kemudian anak fokus memindakhan pion ke sebelah kanan, hasil jawaban benar makajika bingkai atau frame alat peraga edukatif 
dibalik akan menunjukkan warna pion sesuai dengan kunci jawaban yang terletak disebelah kanan atas yang terdapat pada buku BCD's.

5. Proses pemakaian alat peraga edukatif bermain cerdas (BCD's) secara bertahap yaitu : Gambar (1). bentuk cover buku BCD's; Gambar (2). buku dibuka (disesuaikan dengan topik pembahasan) kemudian bingkai atau frame alat peraga edukatif (BCD's) dibuka menjadi dua ruang yaitu sisi kiri dan sisi kanan, kemudian letakkan di atas buku BCD's, sisi kiri frame berupa pion dengan angka 1-16; Gambar (3). langkah berikutnya sesuai dengan pertanyaan yang terdapat pada buku BCD's dan penjelasan dari ibu guru atau orang tua kemudian anak usia dini mulai memindahkan pion dari sisi kiri ke sisi kanan dengan mencocokkan pola gambar yang sama antara buku di sisi kiri dan sisi kanan sampai semua pion di sisi kiri semua pindah ke sisi kanan; Gambar (4) frame di tutup; Gambar (5) frame dibalik kemudian akan terdapat pion yang menunjukkan warna sesuai dengan kunci jawaban yang terdapat pada buku BCD's di posisi kanan atas. Selanjutnya bisa dilihat pada Gambar 9 yang menjelaskan teknis penggunaan dari alat peraga edukatif bermain cerdas (BCD's) sebagai berikut:

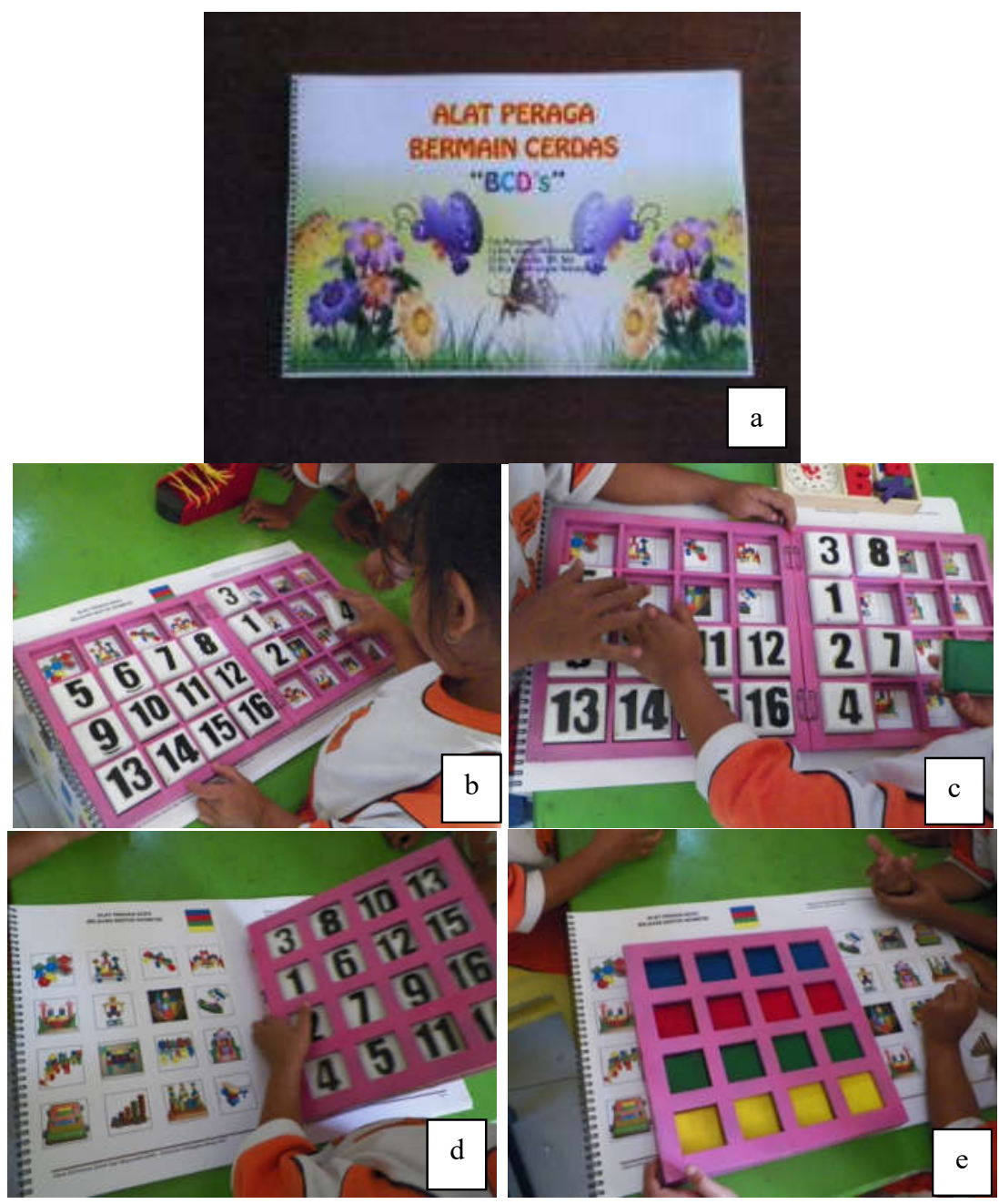

Gambar 9. Cara Kerja Alat Peraga Edukatif BCD’s dari (a), (b), (c), (d), (e)

Sedangkan untuk pendampingan dengan menggunakan alat peraga edukatif bermain cerdas (BCD's) dilakukan kepada guru PAUD Desa Pandansari Kabupaten Malang dan dapat dilihat pada Gambar 10. 


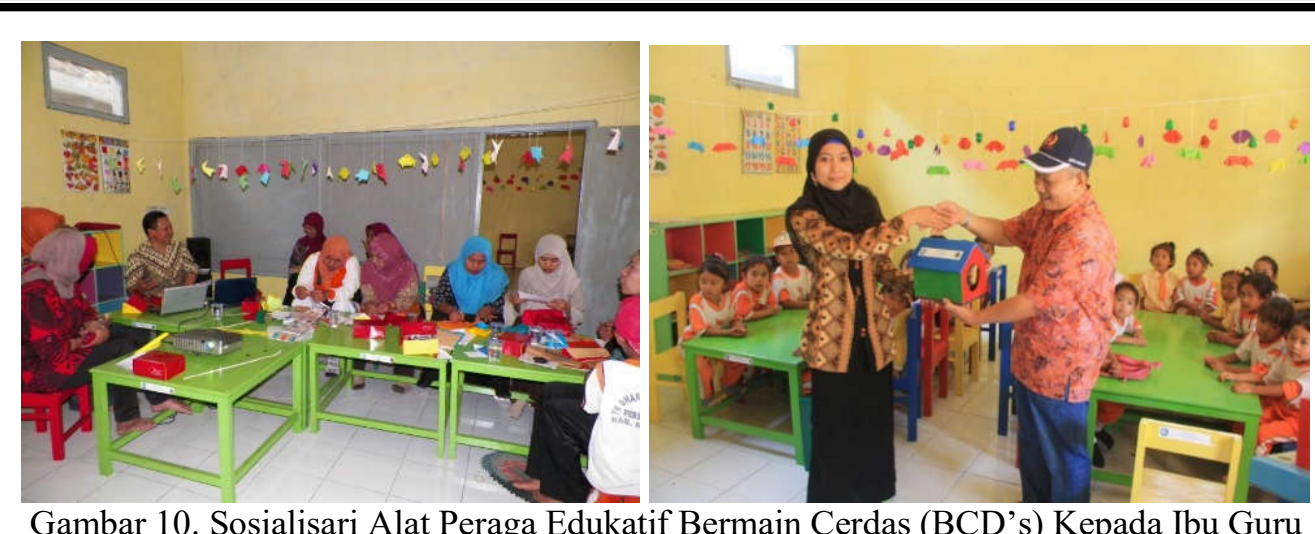

Gambar 10. Sosialisari Alat Peraga Edukatif Bermain Cerdas (BCD’s) Kepada Ibu Guru PAUD Desa Pandansari Kabupaten Malang

\section{DAMPAK DAN MANFAAT}

Pemakaian alat peraga edukatif bermain cerdas (BCD's) memberikan nuansa baru bagi ibu guru dan orang tua dalam memberikan model pembelajaran motorik halus. Pengembangan motorik halus dengan menerapkan pada permainan logika, mengguunakan ketrampilan jari, tangan, berpikir cerdas, dan hati senang membuat anak usia dini tidak jenuh atau cepat bosan belajar. Hal ini dikarenakan alat peraga edukatif bermain cerdas BCD's dikemas dalam bentuk permainan, sedangkan buku peraga dibuat dengan memanfaatkan gambar-gambar yang menarik sehingga anak senang belajar. Media pembelajaran ini sangat membantu guru dalam menerangkan berbagai bentuk konten sesuai dengan Satuan Pembelajaran yang terdapat pada PAUD.

Inovasi alat peraga bermain cerdas (BCD's) mampu menyelesaikan persoalan pada media pembelajaran disekolah PAUD Desa Pandansari Kabupaten Malang. Oleh karena itu keterbatasan media pembelajaran dapat diatasi dengan alat peraga edukatif bermain cerdas (BCD's) dan anak usia dini mampu menyelesaikan setiap tahapan sesuai dengan tema pembelajaran.

\section{Hasil Penilaian Tingkat Efisiensi Penggunaan Alat Peraga Edukatif Bermain Cerdas BCD's}

Pemakaian alat peraga edukatif bermain cerdas (BCD's) menjadi suatu tolok ukur untuk mendapatkan hasil dari sisi efektifitas anak usia dini dalam mengasah motorik halus dengan konten pengenalan garis sehingga mampu mengerjakan selama 4,6 menit. Disamping itu, anak mampu menyebutkan, membedakan dan mengenal berbagai jenis bentuk garis. Pengenalan bertuk geometri bagi anak usia dini mampu mengerjakan selama 5 menit. Dan anak usia dini juga mampu menyebutkan, membedakan bentuk lingkaran, segitiga, tabung, persegi panjang, persegi empat.

Pengenalan angka bisa dikerjakan selama 5,8 menit dari angka 1 sampai dengan 20 dan anak mampu menyebutkan secara lugas, mampu membedakan antara satu angka dengan angka yang lainnya dan juga mampu menyebutkan angka dengan proses di bolakbalik. Anak mampu menyebutkan huruf secara lugas dan perlu waktu yang agak lama sekitar 8 menit untuk 5 jenis huruf. Pengenalan tanaman dalam bentuk bunga mampu disebutkan dengan bagus sebanyak 5 jenis bunga dan waktu yang dibutuhkan 11,4 menit.

Penjumlahan masih membutuhkan waktu yang agak lama yaitu 13,6 menit. Pengurangan angka dengan berbagai model mampu dikerjakan selama 14,9 menit. Anak usia dini masih butuh waktu 15 menit untuk mampu menyelesaikan media bermain cerdas. Berikut ini adalah hasil penilaian dari penggunaan alat peraga edukatif bermain cerdas (BCD's) dan dapat dilihat paga Gambar 11. 


\section{HASIL PENILAIAN PENGGUNAAN ALAT PERAGA EDUKATIF BERMAIN CERDAS BCD's}

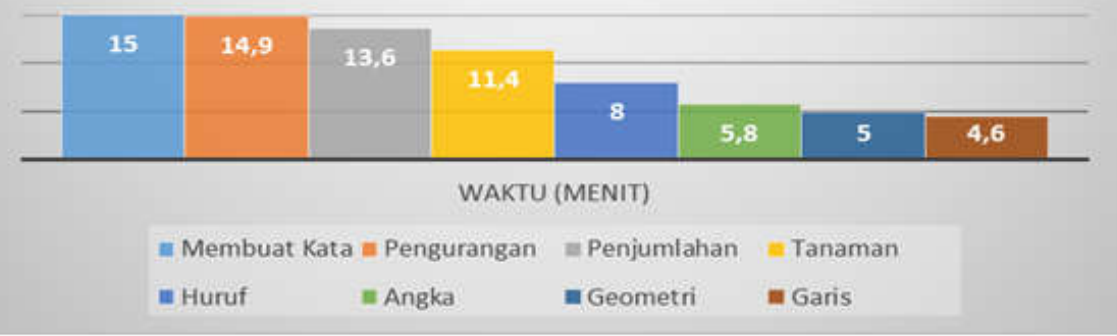

Gambar 11. Hasil Penilaian Anak Usia Dini Dalam Menggunakan Alat Peraga Edukatif Bermain Cerdas (BCD's)

\section{KESIMPULAN}

Alat peraga edukatif bermain cerdas (BCD's) sangat membantu dalam persoalan keterbatasan media pembelajaran yang terdapat di PAUD Desa Pandansari Kabupaten Malang. Mampu membantu ibu guru dalam penyampaian metode belajar yang baru dan lebih inovatif. Media pembelajaran BCD's mampu mengatasi persoalan peningkatan motorik halus anak usia dini, karena media pembelajaran dengan cara bermain. Motorik halus dengan menggunakan jari dan tangan, kecepatan berpikir, mengakibatkan anak usia dini belajar lebih aman dan nyaman hanya dengan media belajar BCD's.

\section{UCAPAN TERIMA KASIH}

Ucapan terimakasih kami sampaikan kepada Rektor Universitas Widyagama Malang yang telah memberikan kesempatan untuk melaksanakan pengabdian kepada masyarakat. Ketua LPPM Universitas Widyagama Malang yang telah memberikan kesempatan artikel pengabdian ini dapat diterima dan dipublikasikan di Jurnal Soliditas, dan kepada mitra yaitu PAUD Desa Pandansari Kabupaten Malang yang telah bersedia untuk dipakai tempat pengabdian kepada masyarakat.

\section{REFERENSI}

Asriah, Nurhasanah, C., \& Yushida. (2021). Pengaruh Stimulasi Alat Permainan Edukatif Berisiko Terhadap Perkembangan Motorik Halus Pada Anak Pra Sekolah 4-5 Tahun di PAUD Al-Yaqin Kecamatan Darul Imarah Kabupaten Aceh Besar Tahun 2019. Jurnal Ilmiah Sains, Teknologi, Ekonomi, Sosial Dan Budaya, 5(3), 72-79.

Evivani, M., \& Oktaria, R. (2020). Permainan Finger Painting Untuk Pengembangan Kemampuan Motorik Halus Anak Usia Dini. Jurnal Warna: Pendidikan Dan Pembelajaran Anak Usia Dini, 5(1), 23-31. https://doi.org/10.24903/jw.v5i1.427

Ilato, A. (2020). Meningkatkan Kemampuan Motorik Halus Dalam Menyusun Sebuah Gambar Melalui Permainan Puzzle Bagi Anak Usia Dini 3-4 Tahun di RA ATTAQWA Matayanagan. Kidspedia: Jurnal Pendidikan Anak Usia Dini, 1(1), 19-23.

Noveradila, S., \& Larasati, D. (2015). Alat Permainan Edukatif Untuk Anak Usia Dini. Jurnal Tingkat Sarjana Senirupa Dan Desain, 1, 7. 
Sulaiman, U., Ardianti, N., \& Selviana. (2019). Tingkat Pencapaian Aspek Perkembangan Anak Usia 5-6 Tahun. NANAEKE: Indonesian Journal of Early Childhood Education, 2(1), 52-65.

Utami, F. (2016). Pengaruh Permainan Konstruktif Terhadap Kemampuan Motorik Halus Anak Usia Dini Pada Kelompok A Ra Mutiara Sunnah Palembang Tahun 2016. Universitas PGRI Palembang.

Yulianto, D., \& Awalia, T. (2017). Meningkatkan Kemampuan Motorik Halus Melalui Kegiatan Montase Pada Anak Kelompok B RA Al-Hidayah Nanggungan Kecamatan Prambon Kabupaten Nganjuk Tahun Pelajaran 2015/2016. Jurnal PINUS, 2(2), 118123. 